\title{
Microstructural and Wear Characteristics of High Velocity Oxygen Fuel (HVOF) Sprayed NiCrBSi-SiC Composite Coating on SAE 1030 Steel
}

\author{
Soner Buytoz • Mustafa Ulutan • Serkan Islak • \\ Bülent Kurt • O. Nuri Çelik
}

Received: 19 January 2011 / Accepted: 22 June 2011 / Published online: 1 February 2013

(C) The Author(s) 2013. This article is published with open access at Springerlink.com

\begin{abstract}
In this paper, wear properties of $\mathrm{NiCrBSi}-\mathrm{SiC}$ coatings were investigated using the ball-on-disk wear test. In experimental study, $\mathrm{NiCrBSi}-\mathrm{SiC}$ powders were sprayed using a high-velocity oxygen fuel technique on an SAE 1030 steel substrate. Powder mixtures with different weight mixing ratios, $\mathrm{NiCrBSi}+10 \mathrm{wt} \% \mathrm{SiC}, \mathrm{NiCrBSi}+20 \mathrm{wt} \% \mathrm{SiC}$ and $\mathrm{NiCrBSi}+40 \mathrm{wt} \% \mathrm{SiC}$ coatings were prepared. The deposited coatings are compared in terms of their phase composition, microstructure and hardness. It is proved that the degree of mixing of the $\mathrm{NiCrBSi}$ and $\mathrm{SiC}$ components in the powder has a massive effect on the phase composition, microstructure and hardness of the coatings. Wear tests were conducted on both the uncoated and coated substrates at same normal load, speed, and wear distance. It has been determined that the coated substrates exhibit a very good tribological performance in comparison to the uncoated substrate. The increase in the adhesive wear resistance provided by the
\end{abstract}

\section{S. Buytoz ( $\square)$ \\ Department of Metallurgy and Materials Engineering, Firat University, Technology Faculty, 23100 Elazig, Turkey e-mail: sbuytoz@gmail.com}

\section{Ulutan · O. Nuri Çelik}

Department of Mechanical Engineering,

Eskisehir Osmangazi University, Eskisehir, Turkey

e-mail: mulutan@ogu.edu.tr

O. Nuri Çelik

e-mail: celikon@gmail.com

\section{S. Islak}

Kastamonu University, Cide Rifat Ilgaz Vocational High School, 37100 Kastamonu, Turkey

e-mail: sislak@kastamonu.edu.tr

\section{B. Kurt}

Department of Materials Engineering, Faculty of Engineering, Bartin University, Nevsehir, Turkey

e-mail: bkurt74@gmail.com coating has been attributed to the presence of a large amount of dispersed $\mathrm{Ni}$ and $\mathrm{Cr}$ carbide and/or borides in the Ni matrix.

Keywords NiCrBSi-based coating $\cdot \mathrm{SiC}$ powder $\cdot \mathrm{HVOF}$. Wear performance

الخلاصسة

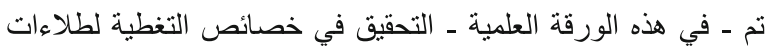

NiCrSiB-SiC

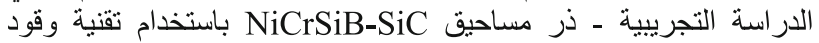

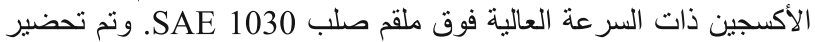

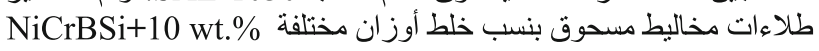
.NiCrBSi+40 wt.\% SiC g NiCrBSi+20 wt.\% SiCو SiC وتمت مقارنة الطلاءات المثبتة بالنسبة لتكوين الحالة والهيكلية متناهية

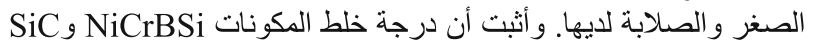

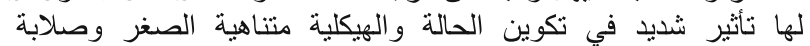
الطلاءات. وقد أجريت اختبار ات التغطية على كل من الملقم المطلي و وغير

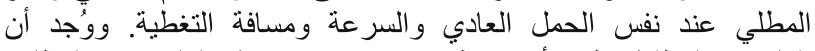

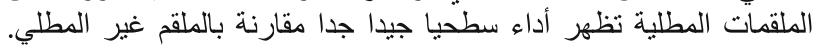

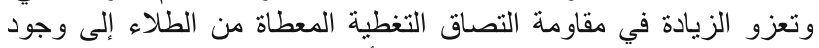

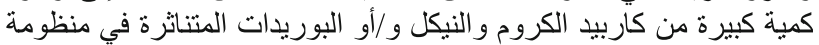
النيكل. (كبل.

\section{Introduction}

High-velocity oxygen fuel (HVOF) is a coating deposition process whereby a powder coating material is heated rapidly in a hot gaseous medium. Simultaneously the powder material is then projected at a high particle velocity onto a prepared substrate surface where it builds up to produce the desired coating [1-3]. High-velocity oxygen fuel (HVOF) sprayed coatings have been used widely throughout the years of the last decade mainly in industrial applications, aerospace, and 
power plants, because the coatings express low porosity and oxide content, high hardness and high adhesion [4-12]. The main advantage of HVOF compared to other thermal spray techniques is the ability to accelerate the melted powder particles of the feedstock material at a relatively large velocity $[13,14]$. The HVOF thermal spraying process has shown to be one of the best methods for depositing conventional Ni-based and NiCr feedstock powders, because the hypersonic velocity of the flame shortens the time of interaction between the powder and the flame [15]. These effects in conjunction with the relatively low temperature (as compared to plasma-based techniques) result in less decomposition of the carbide particles during spraying.

Nickel-based alloys are applied extensively in a number of applications both because of their outstanding wear and corrosion resistance at high temperatures and their relative low cost [16-18]. They have high strength and hardness and good corrosion resistance due to the addition of chromium [19]. Boron brings down the melting temperature and helps in the formation of hard phases. Silicon is added to increase self-fluxing properties. Carbon produces carbides with high hardness levels that improve the wear resistance of coatings $[20,21]$. Considerable research studies were carried out to examine the HVOF coatings [22-27]. Wear and corrosion resistance of NiCrBSi coating deposited using AC-HVOF technique was investigated by Liu et al. [24]. They determined that the excellent wear properties of the Ni-based coating were tested in a dry sliding wear test. The corrosion

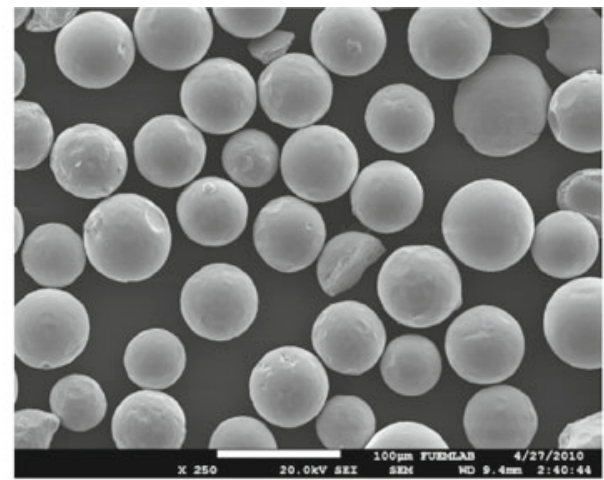

(a)

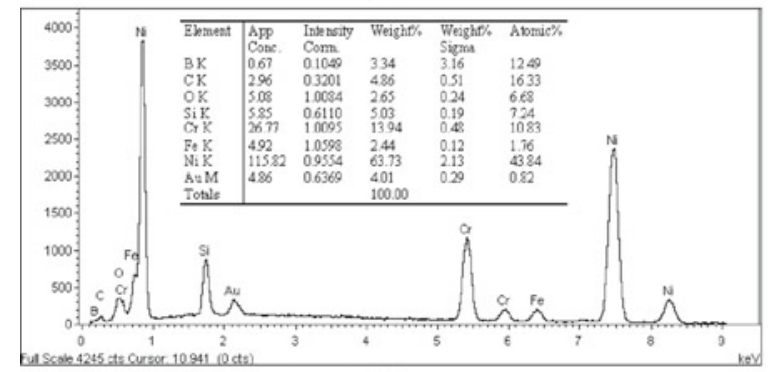

(b)

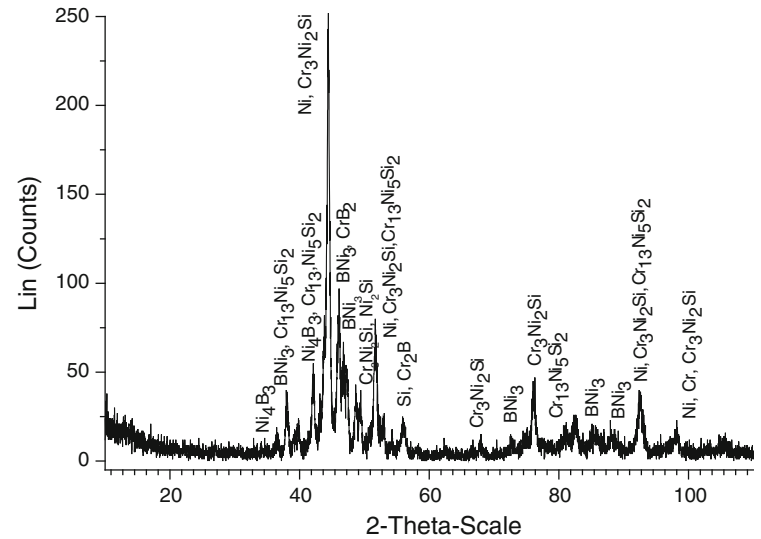

(a)

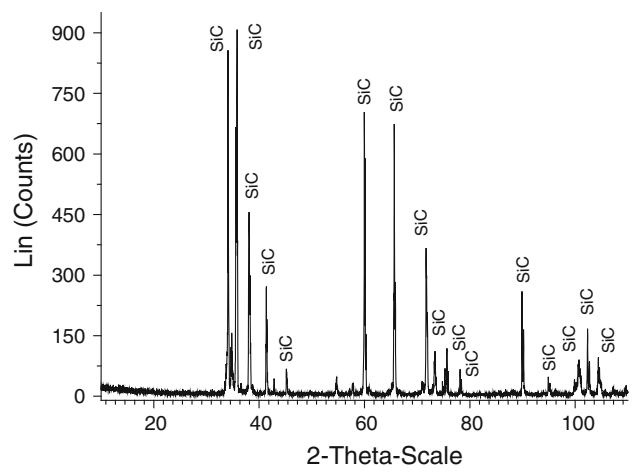

(b)

Fig. 1 XRD analysis of powders: a NiCrBSi and $\mathbf{b} \mathrm{SiC}$

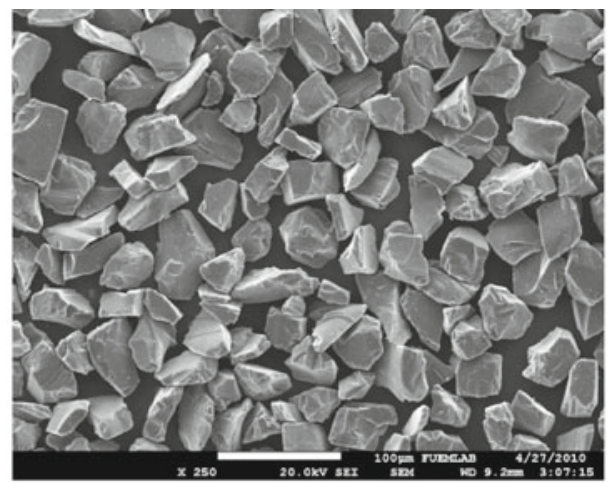

(c)

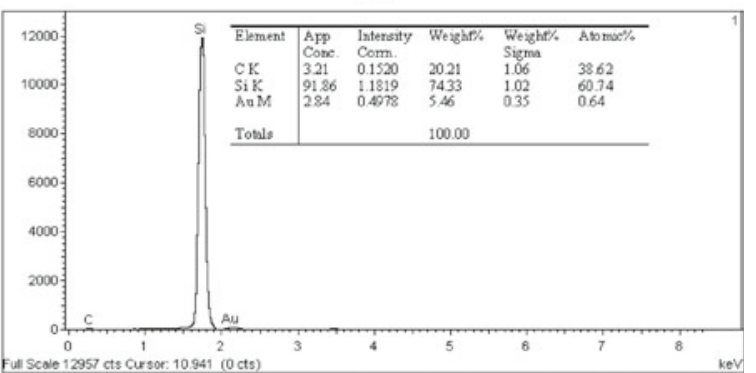

(d)

Fig. 2 SEM micrographs and EDX spectrums of powders used HVOF spray: a, b NiCrBSi powder, $\mathbf{c}$ and $\mathbf{d} \mathrm{SiC}$ powder 
Table 1 Chemical compositions of AISI 1030 steel, NiCrBSi and $\mathrm{SiC}$ powders (wt $\%$ ) used for surface coating

\begin{tabular}{lllllllll}
\hline $\begin{array}{l}\text { Substrate } \\
\text { feedstock } \\
\text { powders }\end{array}$ & \multicolumn{7}{l}{ Composition $(w t \%)$} \\
\cline { 2 - 8 } & $\mathrm{C}$ & $\mathrm{Mn}$ & $\mathrm{Si}$ & $\mathrm{Ni}$ & $\mathrm{Cr}$ & $\mathrm{Fe}$ & $\mathrm{B}$ \\
\hline AISI 1030 steel & 0.32 & 0.58 & 0.21 & 0.45 & 0.095 & Balance & - \\
NiCrBSi powder & 4.86 & - & 5.03 & Balance & 13.94 & 3.97 & 3.34 \\
SiC powder & 20.21 & - & 74.33 & - & - & - & - \\
\hline
\end{tabular}

resistance of the Ni-based coating was found higher than that of the stainless steel substrate material due to the passive film-forming effect of $\mathrm{Cr}$. The hot corrosion behavior of NiCrBSi coatings deposited on $\mathrm{Ni}$ - and $\mathrm{Fe}$-based superalloys was investigated by Sidhu et al. [25]. They showed that structure of the as sprayed NiCrBSi coating mainly consisted of $\gamma$-nickel solid solution containing small fraction of $\mathrm{Cr}_{7} \mathrm{C}_{3}, \mathrm{Ni}_{3} \mathrm{~B}$ phases and $\mathrm{NiCr}_{2} \mathrm{O}_{4}$ spinel oxides. However, they found that the hot corrosion resistance imparted by NiCrBSi coatings may be attributed to the formation of oxides of silicon, chromium, nickel and spinels of nickel and chromium in the molten salt environment at $900{ }^{\circ} \mathrm{C}$. The influence of microstructural and mechanical properties and wear resistance of HVOF-sprayed WC-Co and WC-Ni coatings were examined by Berger et al. [26]. They found that the resistance to erosive wear was improved when cobalt was used as binder metal. The influence of spray parameters on the microstructure and mechanical properties of Colmonoy 88 alloy HVOF coating were studied by Sosa et al. [27]. They determined that the microstructure consists of increase in the unmelted particles volume fraction and the development of interlamellar microcracks as the spraying distance increases, leading to a decrease in the elastic modulus of the coatings. The the adhesion evaluation of different interlayers such as $\mathrm{Co}-\mathrm{Cr}$, Ni-Cr (80-20) HVOF (High Velocity OxyFuel) thermally sprayed coatings and Ni-plating between the cermet-based WC-Co-Cr coatings were examined by Hadad et al. [28]. They indicated that the electrochemically deposited interlayer Ni-plating provides the highest adhesion to cermet coating within the multilayered structured coatings.
The aim of this work was to prepare Ni-based coatings by the HVOF technique and to study their microstructure and properties. The surface properties, such as microstructure and hardness of $\mathrm{NiCrBSi}-\mathrm{SiC}$ coatings prepared by HVOF coating process have been investigated. In particular, the friction and wear behaviors for the $\mathrm{NiCrBSi}-\mathrm{SiC}$ coatings have been analyzed by comparison with each other.

\section{Experimental Procedures}

A mixture of a NiCrBSi powder with an average grain size of $60 \mu \mathrm{m}$ and $\mathrm{SiC}$ powder with an average grain size of $68 \mu \mathrm{m}$ powder was used as spray material. XRD analysis results of the powders are described in Fig. 1a and b. From the morphology of the powder given in Fig. 2, NiCrBSi powders can be observed that the powder completely consists of spherical particles (Fig. 2a) while $\mathrm{SiC}$ powder reveals the angular shape of the ceramic particles (Fig. 2c). The chemical composition of all the materials is summarized in Table 1.

The substrates were pre-cleaned in acetone for $5 \mathrm{~min}$, and then blast-cleaned by 60 mesh aluminum oxides for $5 \mathrm{~min}$ to

Table 2 Spraying parameters

\begin{tabular}{ll}
\hline HVOF gun type & HIPOJET 2100 \\
Oxygen gas pressure (bar) & 7 \\
Fuel gas $\left(\mathrm{C}_{3} \mathrm{H}_{8}\right)$ pressure (bar) & 5 \\
Compressed air pressure (bar) & 5 \\
Powder feed rate $(\mathrm{g} / \mathrm{min})$ & 55 \\
Spray distance $(\mathrm{mm})$ & $180-200$ \\
Gun speed $(\mathrm{mm} / \mathrm{s})$ & 3 \\
Carrier gas $\left(\mathrm{N}_{2}\right)$ pressure (bar) & 5 \\
\hline
\end{tabular}

Table 3 The coating powders with various $\mathrm{SiC}$ contents

\begin{tabular}{lll}
\hline Sample number & Matrice powder content & $\begin{array}{l}\text { Reinforcement powder } \\
\text { content }\end{array}$ \\
\hline Coating-1 & $90 \mathrm{wt} \% \mathrm{NiCrBSi}$ & $10 \mathrm{wt} \% \mathrm{SiC}$ \\
Coating-2 & $80 \mathrm{wt} \% \mathrm{NiCrBSi}$ & $20 \mathrm{wt} \% \mathrm{SiC}$ \\
Coating-3 & $60 \mathrm{wt} \% \mathrm{NiCrBSi}$ & $40 \mathrm{wt} \% \mathrm{SiC}$ \\
\hline
\end{tabular}

Fig. 3 Schematic representation of HVOF system

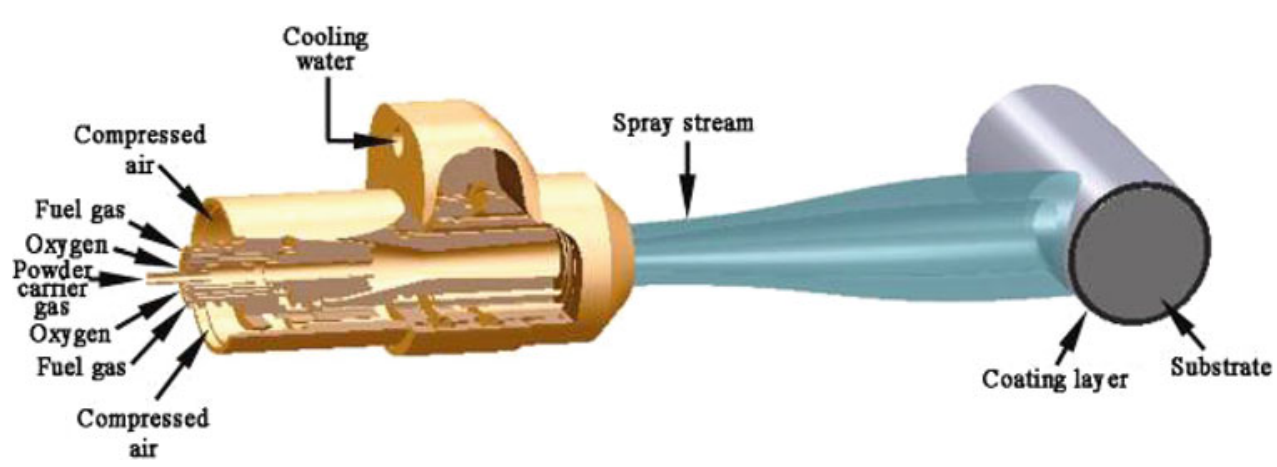



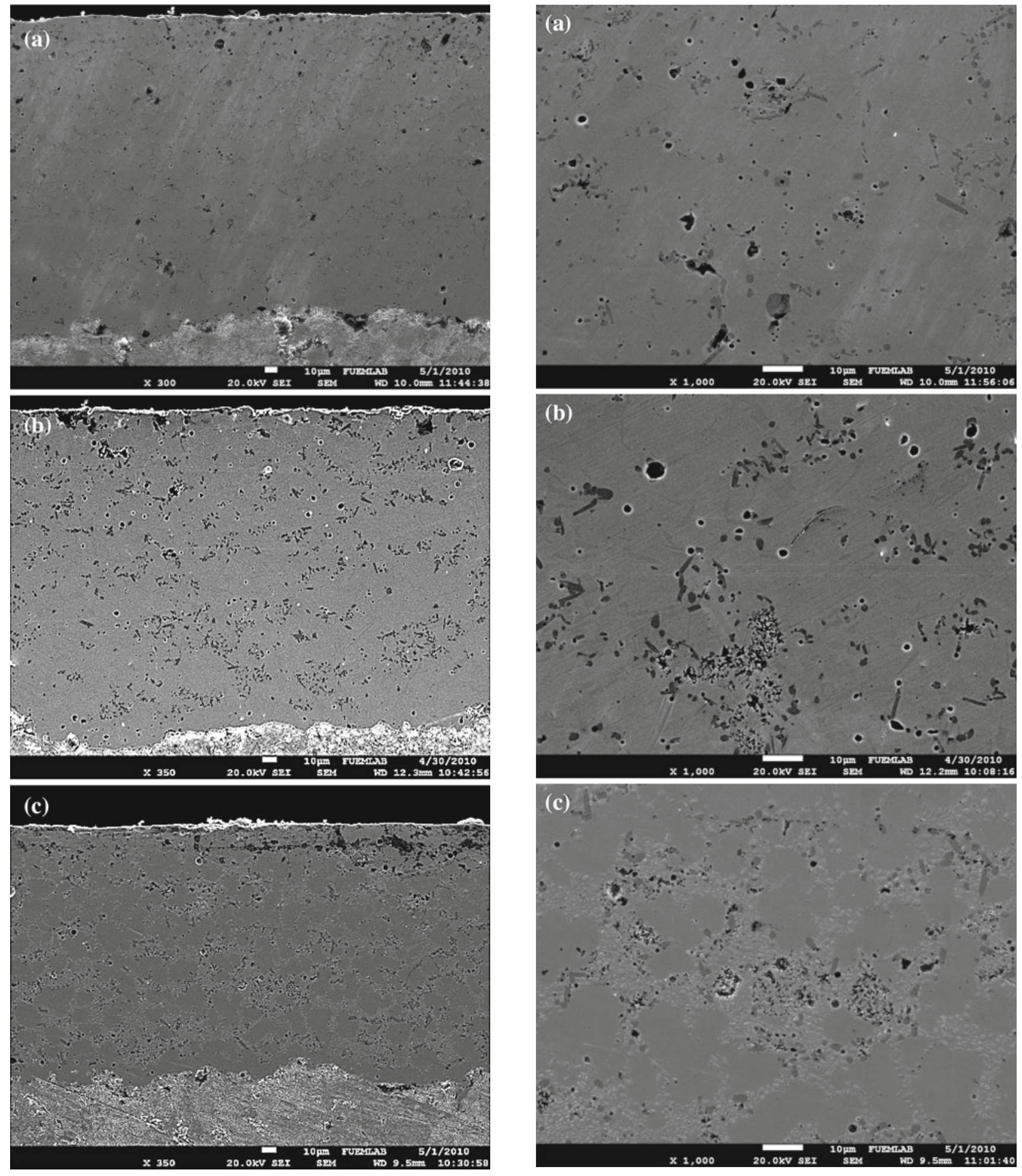

Fig. 4 General view of HVOF coatings on low carbon steel: a coating- 1 , b coating- 2 , and $\mathbf{c}$ coating- 3

Fig. 5 SEM micrographs showing surface morphology of HVOFsprayed $\mathrm{NiCrBSi}-\mathrm{SiC}$ coatings on low carbon steel: a coating-1, b coating-2, and $\mathbf{c}$ coating- 3

improve the adhesion of the coating onto the substrate. The spraying was carried out with the HIPOJET 2100 HVOF system (Kobatek Surface Treatment Industry Co.Ltd. İstanbul,

Turkey). Figure 3 shows the schematic diagram of the coating system. The spraying parameters optimized to produce the coatings on the steel substrate are summarised in Propane 
Fig. 6 EDS analysis result of the coating-3

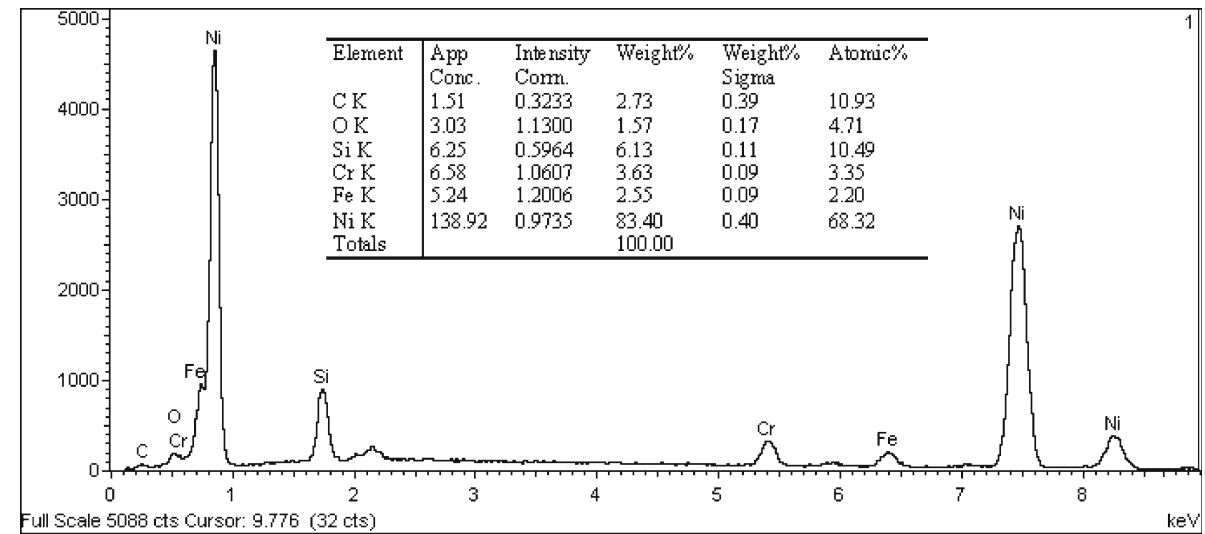

gas was used as a fuel gas. During spraying, the pressures of the propane and oxygen were fixed at 5 bar and 7 bar, respectively. The flow of oxygen was set to $439 \mathrm{l} / \mathrm{min}$. The flow of the propane was 35 and $45 \mathrm{l} / \mathrm{min}$ for NiCrBSi and SiC powders. Nitrogen gas was used as powder feed gas, which was operated at a pressure of $0.35 \mathrm{MPa}$. The spray distance from the gun exit to the substrate surface was kept at 180-200 mm throughout the spraying process.

Three different content NiCrBSi powders were used as feedstock powders in the present investigation, namely (a) 90 wt $\%$ NiCrBSi, (b) $80 \mathrm{wt} \%$ NiCrBSi and (c) $60 \mathrm{wt} \%$ NiCrBSi. The sample codes and coating powders with various SiC content are listed in Table 3. Coatings were then air-cooled. Samples prepared for metallography examinations after coating process were polished with conventional metallography processes after mechanical treatments. Samples polished were etched with ferric chloride etching agent (25 $\mathrm{g} \mathrm{FeCl}_{3}+25 \mathrm{ml} \mathrm{HCl}+100 \mathrm{ml} \mathrm{H}_{2} \mathrm{O}$ ). For each coating, microstructure and phase were investigated using a scanning electron microscope (SEM) and X-ray diffraction (XRD). Surface hardness was measured using an Instron Wolpert tester with a load of $1.96 \mathrm{~N}$ and a loading time of $10 \mathrm{~s}$, and porosity was determined by analyzing images photographed by an optical microscope.

The friction and wear behavior of the coatings were characterized by a linear reciprocating motion with CSM Tribometer at room temperature with a relative humidity of $25-30 \%$ at the dry sliding conditions. $\mathrm{Al}_{2} \mathrm{O}_{3}$ ball (diameter $3 \mathrm{~mm}$ ) was used as the counter body. All tests were performed under a load of $3 \mathrm{~N}$, a maximum linear speed of $2.5 \mathrm{~cm} / \mathrm{s}$, and $4 \mathrm{~mm}$ linear distance. Sliding distance was selected and fixed at $50 \mathrm{~m}$. The coefficient of friction was recorded automatically during the tests (acquisition rate $10 \mathrm{~Hz}$ ). After the wear test, the depth profile of wear trace was measured using a surface profilometer and then wear rates were calculated.

\section{Results and Discussion}

The SEM micrographs at the cross-section of HVOF-sprayed coatings are shown in Fig. 4. The thicknesses of the coatings were measured from the SEM micrographs, taken along the cross-section of the mounted samples. All coatings have a thickness of about $250 \mu \mathrm{m}$ and bond well to the substrate (can be seen in Fig. $4 a-c$ ).

For the HVOF-sprayed nickel-based coating, the typical coating thicknesses are in the range of 250-300 $\mu \mathrm{m}$ as suggested by Sidhu [29]. All coatings were completely crackfree. Moreover, porosity value in the HVOF coatings is also low. The HVOF coating shows a very homogeneous microstructure and a porosity of less than $1 \%$. Adherence between substrate and coating seems to be good with a low presence of either cracks or voids in the interface. Porosity is completely eliminated after the fusion process. A low quantity of unmelted particles is shown in Fig. 4c.

Figure 5 depicts the optical micrograph of the surface of the coatings. The coatings have a uniform microstructure (Fig. 5a and b). Wang et al. [30] study stated that most NiCrBSi particles were completely melted under the present spray conditions. Therefore, the current test results confirm that HVOF coating deposited with the droplets melted sufficiently will not form effective adhesion to a smooth substrate surface. Some limited porosity is visible as dark contrast spots, but generally the coatings have dense structures (Fig. 5b and c). The uniform microstructure of the coatings indicates that a high proportion of the feedstock powder appeared to have melted prior to impact on the substrate. In Fig. 5c, for the coating-3, the results of EDS analysis of the light, grey coloured structure, which appears intensively at the particle borders, are given in Fig. 6 .

According to the analysis results, the structure appearing in the sediment form on the particle borders caused solidification which contains predominantly $\mathrm{C}, \mathrm{Cr}$ and $\mathrm{Fe}$ in small 
Fig. 7 a SEM micrograph and EDX results of coating-2,

b point 1 , c point 2 and d point 3

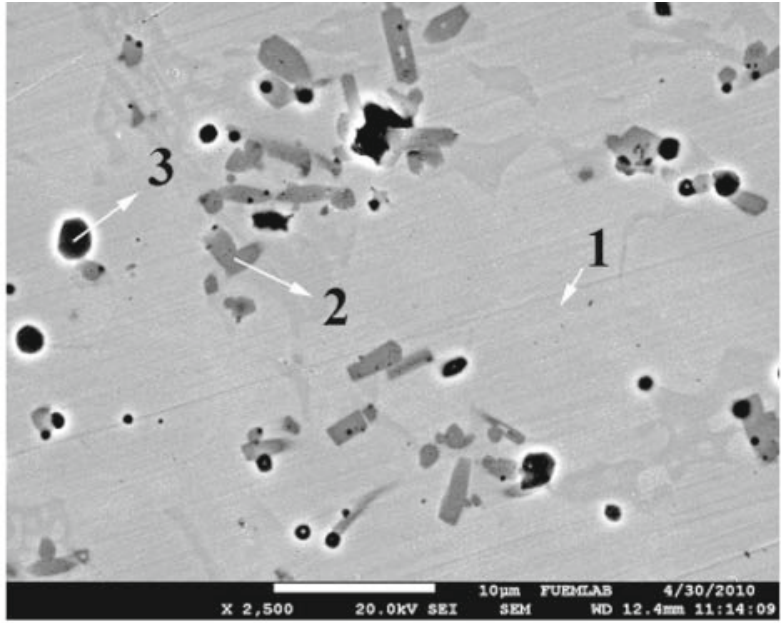

(a)

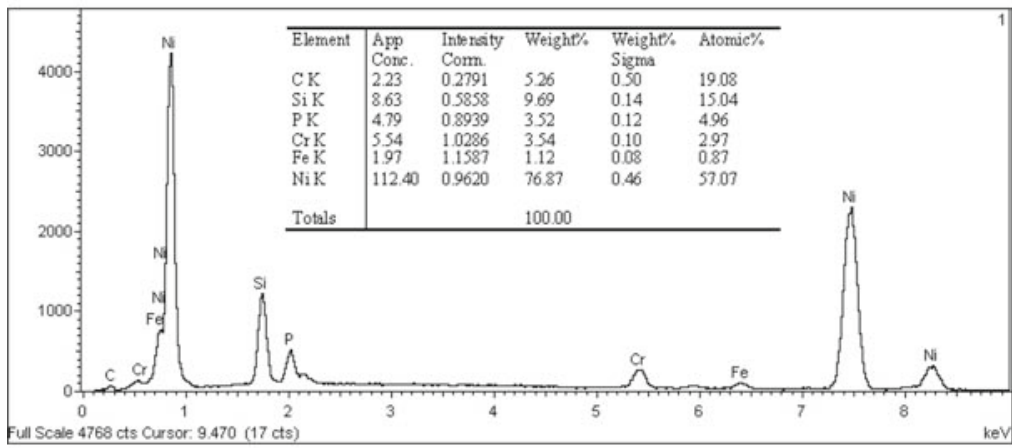

(b)

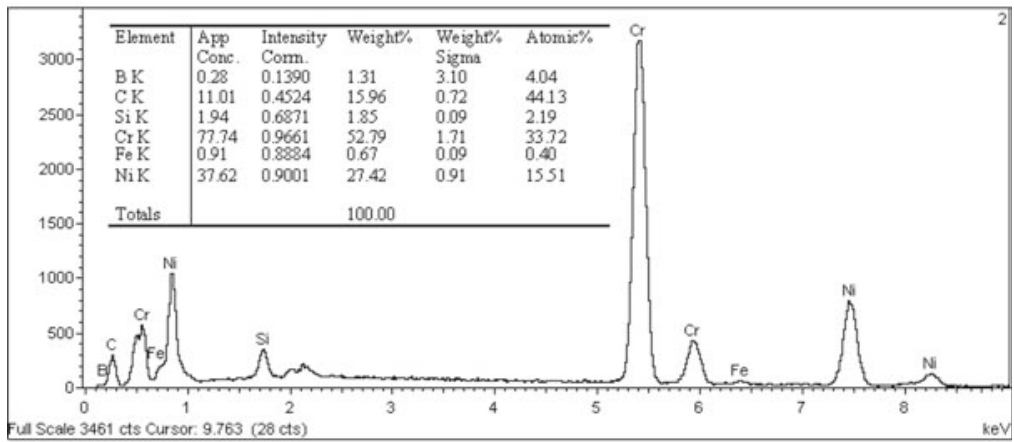

(c)

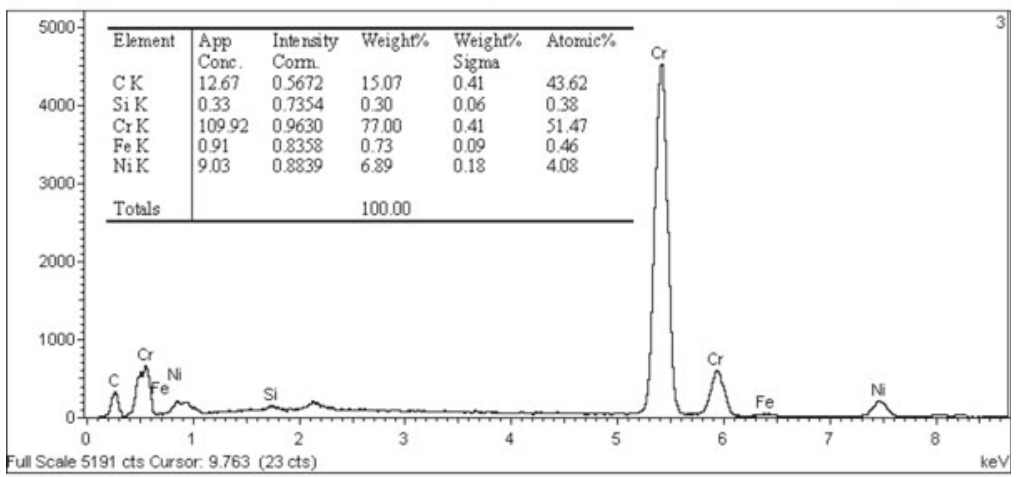

(d) 


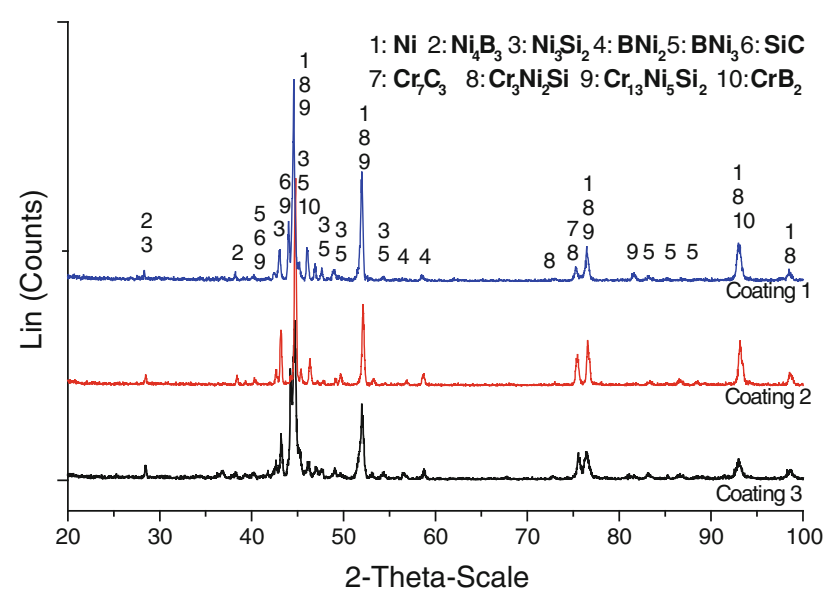

Fig. $8 \mathrm{X}$-ray diffraction for the as-sprayed NiCrBSi-SiC coatings on low alloy steel: a NiCrBSi- $10 \% \mathrm{SiC}$, b NiCrBSi-20\% $\mathrm{SiC}$, c NiCrBSi$40 \% \mathrm{SiC}$

amounts. The fact that there is $\mathrm{O}$ element in small amounts in the structure indicates that the surface has a trend of oxidation. It has resulted from the XRD analysis in Fig. 7 that the possibility of $\mathrm{Ni}_{3} \mathrm{Si}_{2}, \mathrm{Cr}_{3} \mathrm{Ni}_{2} \mathrm{Si}$ and $\mathrm{Cr}_{13} \mathrm{Ni}_{5} \mathrm{Si}_{2}$ phase presence in the structure, which is intensively seen in the particle borders and occurs in the sample labelled with coating-3, is high. Some dark areas that appeared in the coating structure or at the coating substrate interface may be the inclusions.

The SEM micrographs taken from the sample labelled with coating-2 in high resolution and EDS analysis are also given in Fig. 7. As can be seen from Fig. 7a, there exist structures based on Ni matrix material, which are randomly scattered and relatively darker grey coloured. This fact is similar in the coating-3 (Fig. 6c). In Fig. 7a, there are three different structures in SEM microstructure taken from the centre of coating-3 with higher magnification. Based on Ni matrix material, there are structures randomly scattered in, which are relatively dark grey and black. EDS analyses belonging to these structures are given in Fig. 7b, $\mathrm{c}$ and d. As the matrix material involves $19.08 \% \mathrm{C}, 15.04 \% \mathrm{Si}, 4.9 \% \mathrm{P}, 2.97 \% \mathrm{Cr}$, $0.87 \% \mathrm{Fe}, 57.07 \% \mathrm{Ni}$ (Fig. $7 \mathrm{~b}$ ) in atomic scale, the atomic structure with dark grey colour come to occurrence of solidification with the composition given as follows; $4.04 \% \mathrm{~B}$, $44.13 \% \mathrm{C}, 2.19 \% \mathrm{Si}, 33.72 \% \mathrm{Cr}, 0.4 \% \mathrm{Fe}, 15.51 \% \mathrm{Ni}$ (Fig. 7c). According to XRD results given in Fig. 8, the possibility of the fact that this dark grey coloured structure is $\mathrm{CrB}_{2}, \mathrm{Cr}_{3} \mathrm{Ni}_{2} \mathrm{Si}$ and/or $\mathrm{Cr}_{7} \mathrm{C}_{3}$ is high. The similar findings are achieved by Abdi and Labaili [31] and Planche et al. [32]. EDS analysis of the dark structure marked with number 3 in Fig. 7a is given in Fig. 7d. This structure exists in all three samples. The probability of being $\mathrm{Cr}_{7} \mathrm{C}_{3}$ of this structure is rather high. In case of spraying onto the coating surface, the mixture of $\mathrm{NiCrBSi}$ and $\mathrm{SiC}$ coating powder decomposes due to high temperature, and then forms new phases by re-solidi- fying during the fusing to the base material. For the structure to be $\mathrm{Cr}_{7} \mathrm{C}_{3}$ complies with the XRD results given in Fig. 8 .

Figure 8 shows the XRD patterns for the HVOF-sprayed $\mathrm{NiCrBSi}-\mathrm{SiC}$ coatings and it is evident that the coatings mainly consist of $\gamma$-nickel-based face-centred cubic (fcc) structure as a principal phase. This situation is a feature common in all the nickel-based coated [24-33]. XRD patterns of the coatings have also revealed the presence of very low intensity peaks of $\mathrm{Ni}_{4} \mathrm{~B}_{3}, \mathrm{BNi}_{2}, \mathrm{BNi}_{3}, \mathrm{SiC}$ and $\mathrm{Cr}_{7} \mathrm{C}_{3}$ phases. Furthermore, very weak peaks, indexed as belonging to $\mathrm{Cr}_{3} \mathrm{Ni}_{2} \mathrm{Si}, \mathrm{Cr}_{13} \mathrm{Ni}_{5} \mathrm{Si}_{2}$ and $\mathrm{CrB}_{2}$ are identified.

The SEM micrographs and elemental variations across the cross-section of HVOF-coated materials are shown in Fig. 9. EDAX analysis of coating-1 (Fig. 9a) reveals that the concentration of $\mathrm{Ni}, \mathrm{Cr}$ and $\mathrm{C}$ decreases at point 1 , whereas at points 2, 3 and 4, the amounts of $\mathrm{Cr}$ are relatively more. Quantity of $\mathrm{Ni}$ only increased at point 2 , but this element is at its minimal value at the point 4. EDAX analysis of coating-2 (Fig. 9b) shows that the $\mathrm{Ni}$ and $\mathrm{C}$ elements are almost constant at point $1-5$. Although quantity of $\mathrm{Cr}$ is higher at point 3 , the concentration of $\mathrm{Cr}$ is the lowest at point 5. As Fig. 9c reveals, for EDAX analysis results of coating-3, the weight percentage of $\mathrm{Si}, \mathrm{C}$ and $\mathrm{O}$ increases at point 5 where $\mathrm{Ni}$ decreases substantially signifying that dark contrast phase at the top of scale might be rich with oxides of $\mathrm{Cr}, \mathrm{C}$ and $\mathrm{Si}$. The existence of higher oxygen at point 5 might lead to the formation of $\mathrm{Cr}$ - and Si-rich oxide scale. The dark, black phase present at the upper point of the coating (point 5) is rich with $\mathrm{Si}$ and $\mathrm{C}$ unmelted $\mathrm{SiC}$ particles. It is believed that $\mathrm{SiC}$ grains might be retained due to inadequate time to find for the deposition and re-solidification of molten or semi-molten droplets. Both XRD analysis results (can be seen in Fig. 8) and EDAX analysis results (can be seen in Figs. 7 and 9) reveal that the major phase of NiCrBSi-SiC coating is austenite structure rich with $\mathrm{Ni}, \mathrm{Cr}, \mathrm{C}$ and $\mathrm{Si}$.

The microhardness data of the coatings are shown in Fig. 10a, which shows the microhardness profiles along the cross-section of the coatings as a function of distance from the coating-substrate interface (Fig. 10b). The microhardness of the substrate is in the range $210-230 \mathrm{Hv}$. The microhardness of the coatings is found to be variable with the distance from the coating-substrate interface. This significant variation in the microhardness along the thickness of the coatings might be due to the distribution of the $\mathrm{SiC}$ hard phase in $\mathrm{Ni}$ based alloy matrix. Maximum value of about $831 \mathrm{Hv}$ was obtained from the coating- 3 , while sample 1 showed minimum values of about $474 \mathrm{Hv}$. Microhardness for coating-2 is $750 \mathrm{Hv}$. Further, an increase in microhardness of all the substrates was observed near the coating-substrate interface.

The average coefficient of friction and wear rate values of all samples coated with $\mathrm{NiCrBSi}+\mathrm{SiC}$ via the HVOF method were determined to be smaller than that of the original material (Fig. 11). Especially for the coating-3 sample to which 
Fig. 9 SEM micrographs and variations of elemental composition across the cross-section of HVOF coated with $\mathrm{NiCrBSi}$ and $\mathrm{SiC}$ mixed powders: a coating-1, b coating- 2 and c coating-3
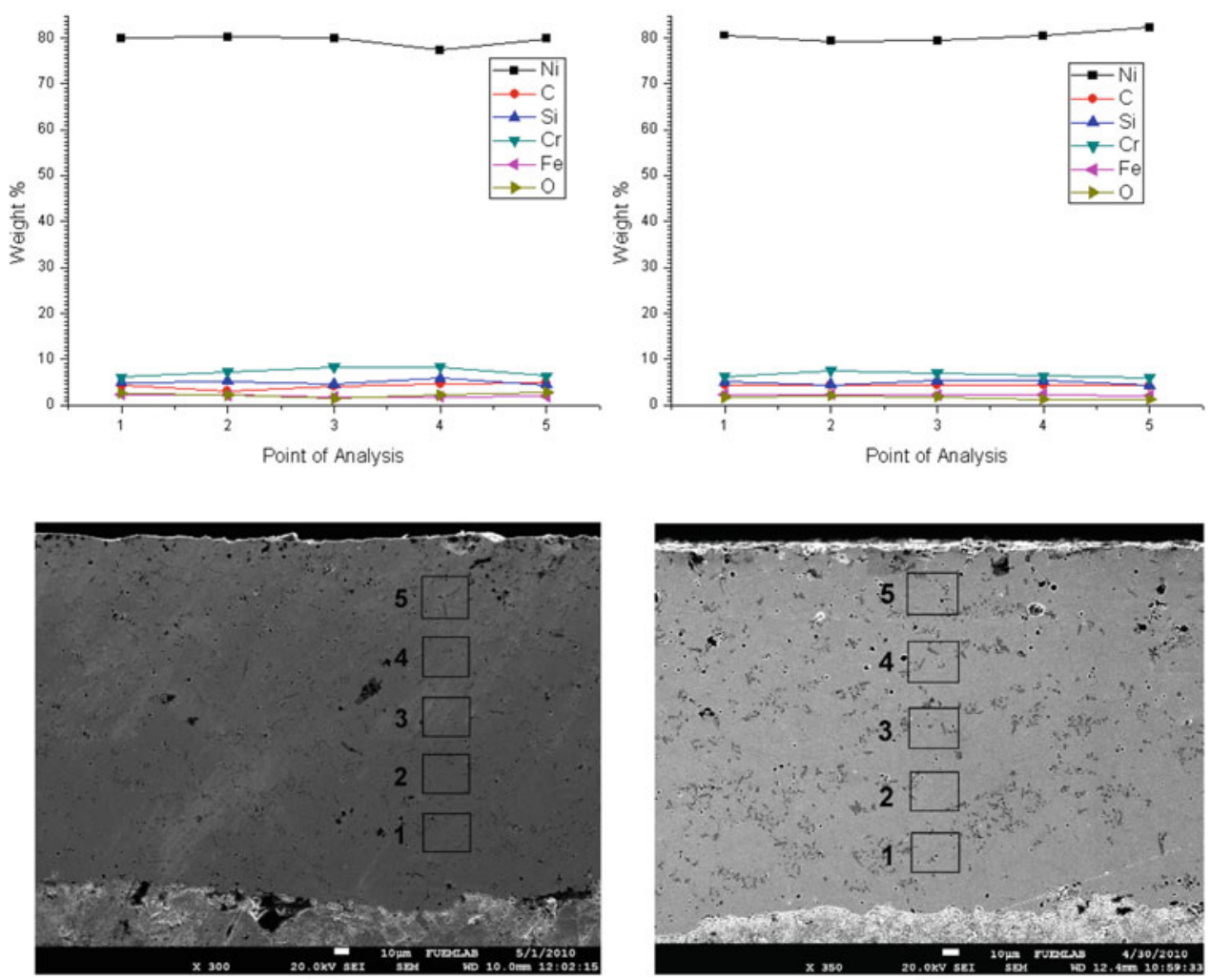

(a)

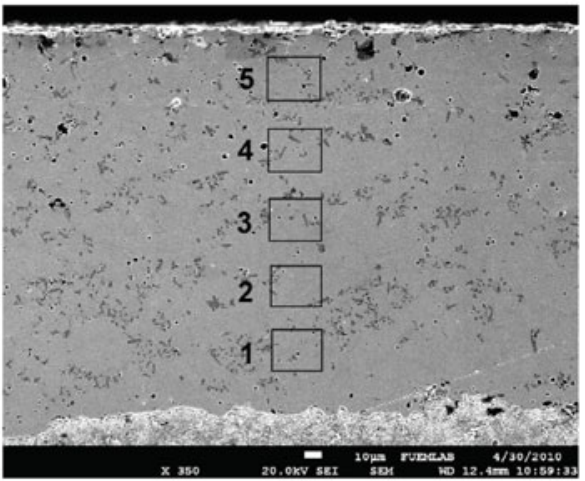

(b)
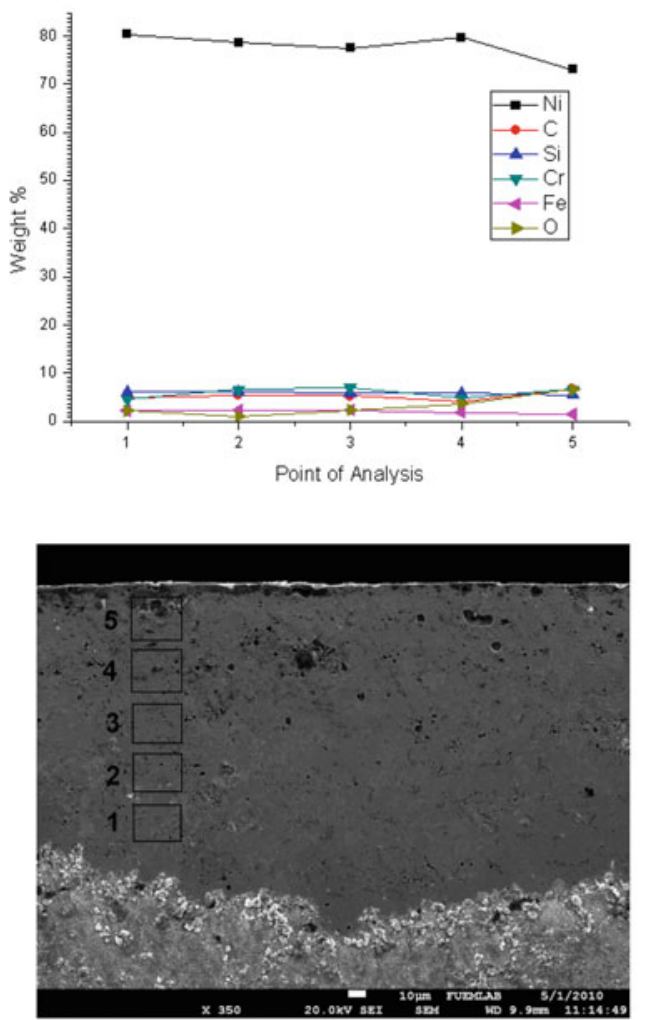

(c) 


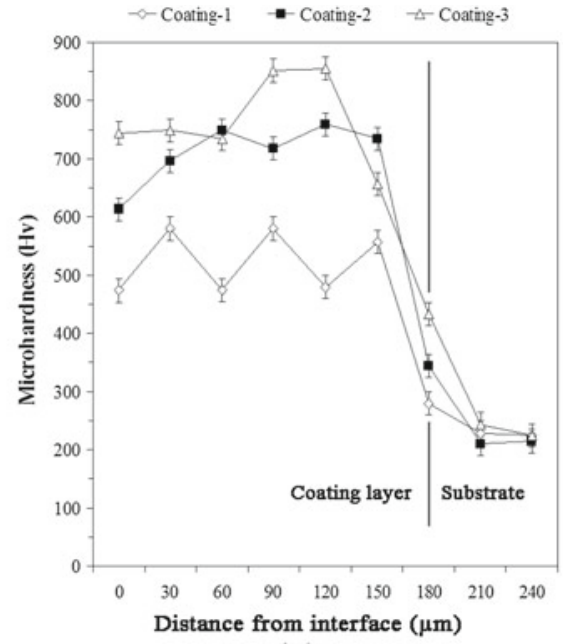

(a)

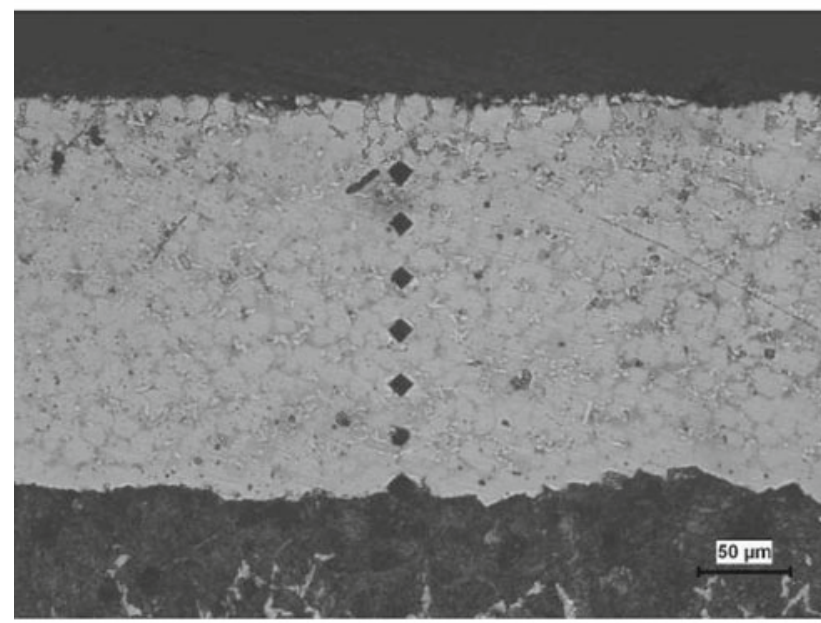

(b)

Fig. 10 a Microhardness distributions of the coating layers and $\mathbf{b}$ Hardness indentations through the coating layer for coating-2 highest amount of $\mathrm{SiC}$ powder was added it has decreased to half its original value. Increased hardness and grain refining of particles due to increased $\mathrm{SiC}$ powder quantity has affected this result. As a result of the experiments conducted under the same conditions the coefficient of friction and wear rate of low carbon SAE 1030 steel was determined to be at their highest levels. Abrasive wear is observed clearly in the EDS analysis of worn surface (Fig. 12a). Also the weak iron oxides that are formed and break up during the experiment thus increasing wear rate. Significant decreases have been obtained for the coefficients of friction and wear rate due to the Ni containing oxides (Fig. 12b and c) that form on the surface of coating- 1 and -2 . In coating- 3 sample, adhesive (oxidative) wear has been observed due to the lubricating effect of strong oxides (Fig. 12d) that absorb the carbon which has increased due to the dissolution of $\mathrm{SiC}$ powder.

Tribochemical reaction between water vapor and $\mathrm{SiC}$ controls the tribological behaviour in these coatings. In coating1 and -2 , forms of microcracks networks that are similar to "mud cracks" can be seen. These cracks decrease from coating- 1 to coating- 3 . These cracks can cause increase of the coefficient of friction. This result is in good agreement with Stachowiak [34].

\section{Conclusions}

1. Under the employed spray conditions, $\mathrm{NiCrBSi}$ and $\mathrm{SiC}$ mixed powders have been deposited by HVOF process to develop coatings of average $250 \mu \mathrm{m}$ thick on SAE 1030 steel substrates. Microhardness of the coatings is found in the range $550-830 \mathrm{Hv}$, which is higher than that of the substrate material.

2. The microstructure of the as-sprayed coating has a nickel-based fcc structure as the principal phase. XRD
Fig. 11 Coefficent of friction and the wear rate values of the of the coatings

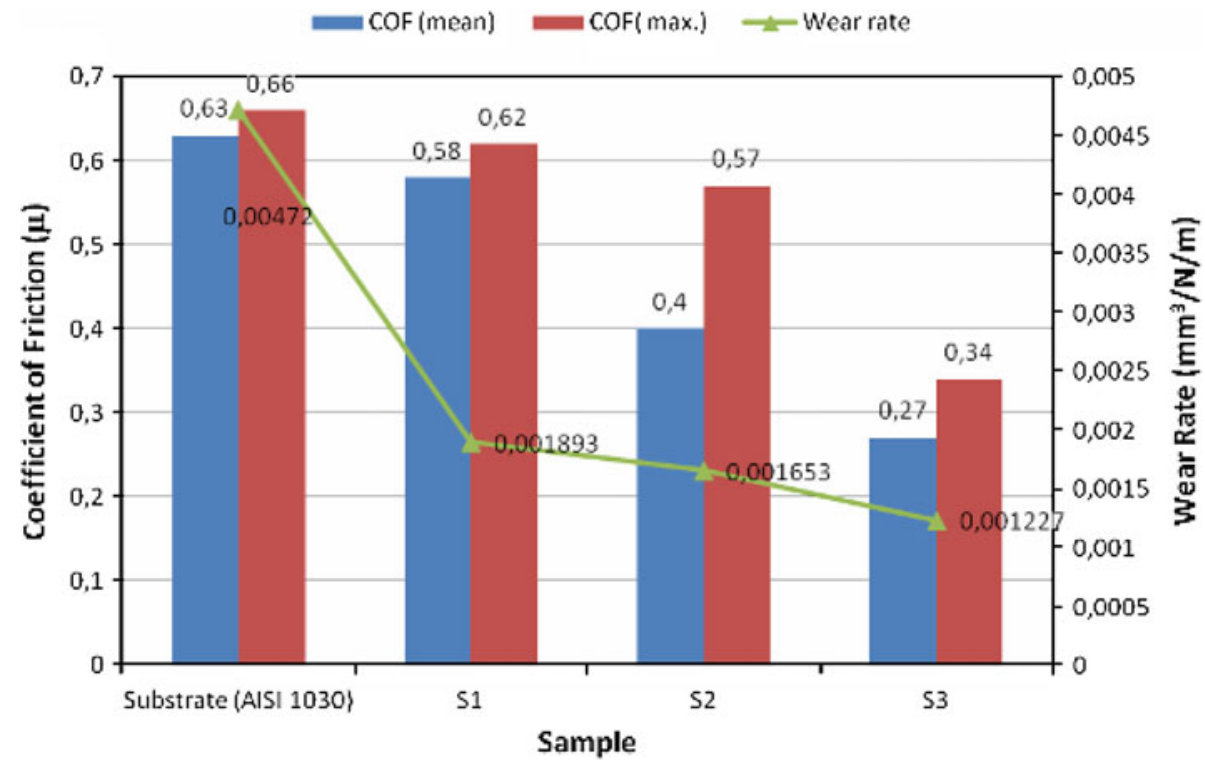




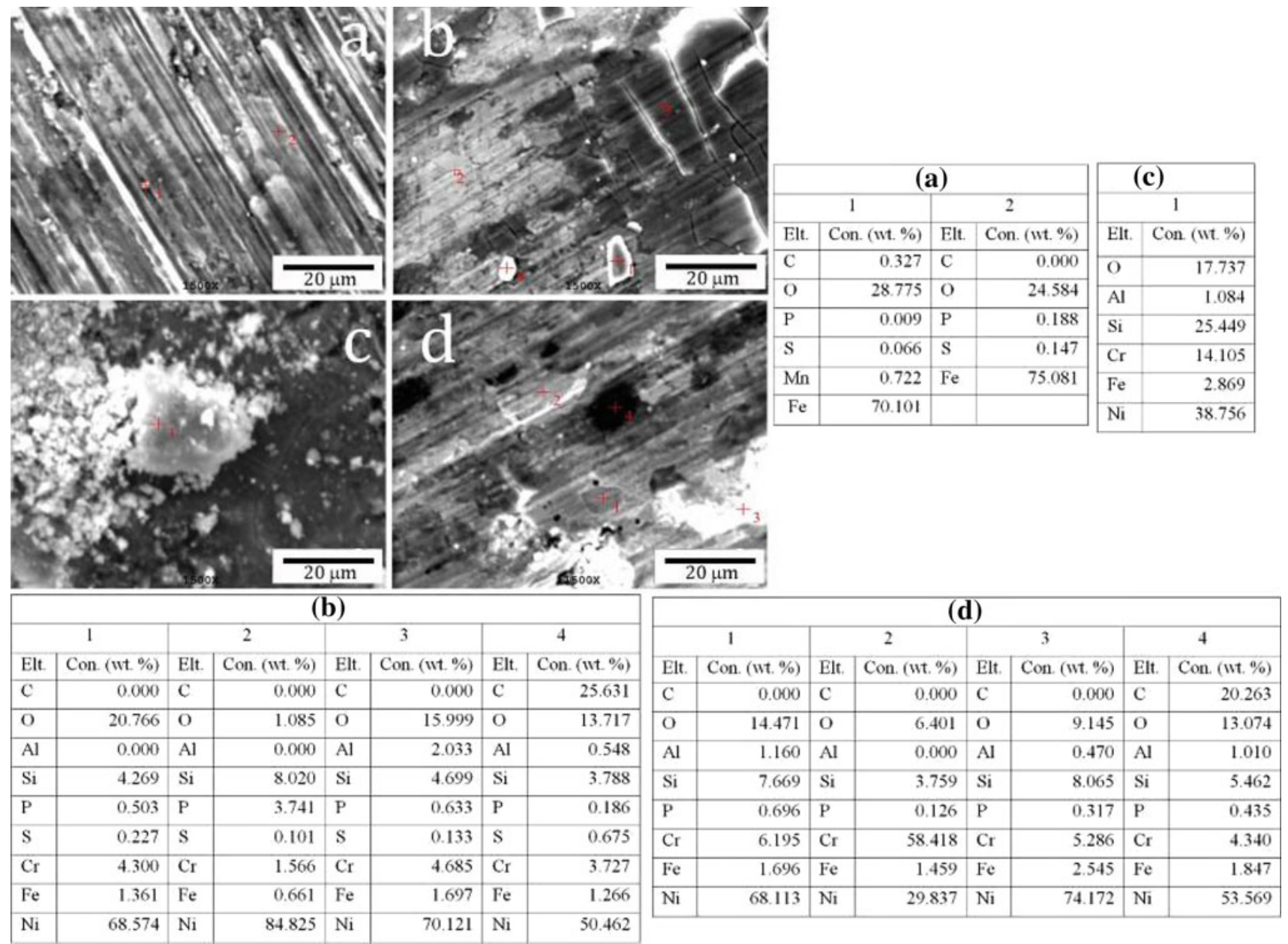

Fig. 12 EDS analysis results of the worn surfaces: a substrate, $\mathbf{b}$ coating-1, $\mathbf{c}$ coating-2, and $\mathbf{d}$ coating-3

analysis of the coating microstructures revealed the presence of low intensity peaks of $\mathrm{Ni}_{4} \mathrm{~B}_{3}, \mathrm{BNi}_{2}, \mathrm{BNi}_{3}$, $\mathrm{SiC}$ and $\mathrm{Cr}_{7} \mathrm{C}_{3}$ phases. Furthermore, very weak peaks, indexed as belonging to $\mathrm{Cr}_{3} \mathrm{Ni}_{2} \mathrm{Si}, \mathrm{Cr}_{13} \mathrm{Ni}_{5} \mathrm{Si}_{2}$ and $\mathrm{CrB}_{2}$ are identified.

3. Coefficents of friction and wear rate of all HVOF coating-applied samples were lower than that of the SAE 1030 steel. The increase in the amount of SiC powder positively influenced the coefficent of friction and the wear rate of the samples.

Acknowledgments The authors would like to thank Mr. Rakim Tuncer of KOBATEK Surface Treatment Industry Company of Turkey for performing HVOF.

Open Access This article is distributed under the terms of the Creative Commons Attribution License which permits any use, distribution, and reproduction in any medium, provided the original author(s) and the source are credited.

\section{References}

1. Herman, H.; Sampath, S.; McCune, R.: Thermal spray: current status and future trends. Mat. Res. Soc. Bull. 25(7), 17-25 (2000)

2. Crawmer, D.E.: Thermal spray processes. In: Davis, J.R. (ed.), Handbook of Thermal Spray Technology, pp. 54-76. ASM International, Materials Park (2006)

3. Pawlowski, L.: The Science and Engineering of Thermal Spray Coatings. 2nd edn., pp. 85-89. Wiley, Chichester (2008)

4. Davis, J.R. (ed.): Handbook of Thermal Spray Technology, pp. 175-213. ASM International, Materials Park (2006)

5. Scrivani, A.; Ianelli, S.; Rossi, A.; Groppetti, R.; Casadei, F.; Rizzi, G.: A contribution to the surface analysis and characterisation of HVOF coatings for petrochemical application. Wear 250, 107-113 (2001)

6. Mann, B.S.; Arya, V.; Joshi, P.: Advanced high-velocity oxygenfuel coating and candidate materials for protecting $1 \mathrm{l}$ steam turbine blades against droplet erosion. J. Mater. Eng. Perform. 14, 487-494 (2005)

7. Rastegar, F.; Richardson, D.E.: Alternative to chrome: HVOF cermet coatings for high horse power Diesel engines. Surf. Coat. Technol. 90, 156-163 (1997) 
8. Mann, B.S.; Arya, V.; Maiti, A.K.; Rao, M.U.B.; Joshi, P.: Corrosion and erosion performance of HVOF/TiAlN PVD coatings and candidate materials for high pressure gate valve application. Wear 260, 75-82 (2006)

9. Wheeler, D.W.; Wood, R.J.K.: Erosion of hard surface coatings for use in offshore gate valves. Wear 258, 526-536 (2005)

10. Chivavibul, P.; Watanabe, M.; Kuroda, S.; Komatsu, M.: Evaluation of HVOF-sprayed WC-Co coatings for wood machining, Surf. Coat. Technol. 202, 5127-5135 (2008)

11. Mann, B.S.; Arya, V.: HVOF coating and surface treatment for enhancing droplet erosion resistance of steam turbine blades. Wear 254, 652-667 (2003)

12. Moskowitz, L.; Trelewicz, K.: HVOF coatings for heavy-wear, high-impact applications. J. Therm. Spray Technol. 6, 294-299 (1997)

13. Dongmo, E.; Wenzelburger, M.; Gadow, R.: Analysis and optimization of the HVOF process by combined experimental and numerical approaches. Surf. Coat. Technol. 202, 4470-4478 (2008)

14. Kamnis, S.; Gu, S.; Lu, T.J.; Chen, C.: Computational simulation of thermally sprayed WC-Co powder. Comput. Mater. Sci. 43, 11721182 (2008)

15. González, R.; García, M.A.: Peñuelas, I.; Cadenas, M.; del Rocío Fernández, Ma.; Hernández Battez, A.; Felgueroso, D.: Microstructural study of NiCrBSi coatings obtained by different processes. Wear 263 (1-6), 619-624 (2007)

16. Navas, C.; Colaço, R.; de Damborenea, J.; Vilar, R.: Abrasive wear behaviour of laser clad and flame sprayed-melted NiCrBSi coatings. Surf. Coat. Technol. 200(24), 6854-6862 (2006)

17. Wang, X.; Zhang, M.; Zou, Z.; Qu, S.: Microstructure and properties of laser clad $\mathrm{TiC}+\mathrm{NiCrBSi}+$ rare earth composite coatings. Surf. Coat. Technol. 161 (2-3), 195-199 (2002)

18. Lin, M.C.; Chang, L.S.; Lin, H.C.; Yang, C.H.; Lin, K.M.: A study of high-speed slurry erosion of NiCrBSi thermal-sprayed coating. Surf. Coat. Technol. 201(6), 3193-3198 (2006)

19. Mankins, W.L.; Lamb, S. (eds.): Nickel and Nickel Alloys. ASM Handbook, vol. 2, pp. 1362-1404. ASM International (1992)

20. Miguel, J. M.; Guilemany, J. M.; Vizcaino, S.: Tribological study of NiCrBSi coating obtained by different process. Tribol. Int. 36(3), 181-187 (2003)

21. Gómez-del Río, T.; Garrido, M.A.; Fernández, J.E.; Cadenas, M.; Rodríguez, J.: Influence of the deposition techniques on the mechanical properties and microstructure of NiCrBSi coatings. J. Mater. Process. Technol. 204(1-3), 304-312 (2008)

22. Sidhu, T.S.; Prakash, S.; Agrawal, R.D.: Characterisation of NiCr wire coatings on Ni- and Fe-based superalloys by the HVOF process. Surf. Coat. Technol. 200(18-19), 5542-5549 (2006)

23. Gaona, M.; Lima, R.S.; Marple, B.R.: Influence of particle temperature and velocity on the microstructure and mechanical behaviour of high velocity oxy-fuel (HVOF) -sprayed nanostructured titania coatings. J. Mater. Process. Technol. 198(1-3), 426-435 (2008)
24. Liu, S.; Zheng, X.; Geng, G.: Dry sliding wear behavior and corrosion resistance of NiCrBSi coating deposited by activated combustion-high velocity air fuel spray process. Mater. Des. 31(2), 913-917 (2010)

25. Sidhu, T.S.; Prakash, S.; Agrawal, R.D.: Characterisations of HVOF sprayed NiCrBSi coatings on Ni- and Fe-based superalloys and evaluation of cyclic oxidation behaviour of some Ni-based superalloys in molten salt environment. Thin Solid Films 515(1), 95-105 (2006)

26. Berger, L.-M.; Saaro, S.; Naumann, T.; Wiener, M.; Weihnacht, V.; Thiele, S.; Suchánek, J.: Microstructure and properties of HVOFsprayed chromium alloyed WC-Co and WC-Ni coatings. Surf. Coat. Technol. 202(18), 4417-4421 (2008)

27. La Barbera-Sosa, J.G.; Santana, Y.Y.; Villalobos-Gutiérrez, C. Cabello-Sequera, S.; Staia, M.H.; Puchi-Cabrera, E.S.: Effect of spray distance on the corrosion-fatigue behavior of a mediumcarbon steel coated with a Colmonoy 88 alloy deposited by HVOF thermal spray. Surf. Coat. Technol. (In Press), Corrected Proof, Available online $1 \mathrm{Feb} 2010$

28. Hadad, M.; Hitzek, R.; Buergler, P.; Rohr, L.; Siegmann, S.: Wear performance of sandwich structured $\mathrm{WC}-\mathrm{Co}-\mathrm{Cr}$ thermally sprayed coatings using different intermediate layers. Wear 263(1-6), 691699 (2007)

29. Sidhu, T.S.; Prakash, S.; Agrawal, R.D.: Studies of the metallurgical and mechanical properties of high velocity oxy-fuel sprayed stellite-6 coatings on Ni- and Fe-based superalloys. Surf. Coat. Technol. 201(1-2), 273-281 (2006)

30. Wang, Y.-Y.; Li, C.-J.; Ohmori, A.: Examination of factors influencing the bond strength of high velocity oxy-fuel sprayed coatings. Surf. Coat. Technol. 200(9), 2923-2928 (2006)

31. Abdi, S.; Lebaili, S.: Alternative to chromium, a hard alloy powder NiCrBCSi (Fe) coatings thermally sprayed on 60CrMn4 steel. Phase and comportements. Phys. Proc. 2, 1005-1014 (2009)

32. Planche, M.P.; Liao, H.; Normand, B.; Coddet, C.: Relationships between NiCrBSi particle characteristics and corresponding coating properties using different thermal spraying processes, Surface and Coatings Technology, 200(7), 2465-2473 (2005)

33. Chaliampalias, D.; Vourlias, G.; Pavlidou, E.; Skolianos, S.; Chrissafis, K.; Stergioudis, G.: Comparative examination of the microstructure and high temperature oxidation performance of $\mathrm{NiCrBSi}$ flame sprayed and pack cementation coatings. Appl. Surf. Sci. 255(6), 3605-3612 (2009)

34. Stachowiak, G. (ed.): Wear-Materials, Mechanisms and Practice, Tribology in Practice Series, pp. 1-458. Wiley, Hoboken (2005) 